\title{
ENGINEERING ASSESSMENT OF A LOCAL ROAD CONSTRUCTED FROM BAUXITE RESIDUE
}

\author{
ANASTASIOS MOURATIDIS ${ }^{1} \&$ IRO PERNIENTAKI ${ }^{2}$ \\ ${ }^{1}$ Laboratory of Highway Engineering, Aristotle University of Thessaloniki, Greece \\ "Aluminium of Greece", Greece
}

\begin{abstract}
Bauxite residue, also called red mud, is the solid remainder of the bauxite industrial treatment by the Bayer process. During the last two decades, significant research has been undertaken to suggest potential effective use of the material, including extraction of rare metals, production of ceramics, painting agents, fertilizers, use in cement industry (iron/alumina source in clinker), and other industrial applications. However, potential use of this by-product in highway engineering projects, which engage big volumes of earthwork, is far from being fully investigated. This beneficial combination of a resistant "high-added value" structure, indirectly producing a positive environmental impact, makes the use of bauxite residue in engineering applications interesting and promising. This paper presents the engineering assessment of an asphalt road constructed from bauxite residue in the industrial site of the "Aluminium of Greece". The construction (2009-2011) was based on the results of laboratory and site investigation of the properties of the by-product. After 9 years of full traffic conditions, a comprehensive assessment has been recently undertaken to detect any deficiencies of the road structure and to determine the performance of the BR pavement over time. The site investigation was mainly directed at the appraisal of surface pavement distress unveiling structural defects of the BR structure. The results of this investigation indicate an absolutely satisfactory pavement performance under heavy load conditions. Moreover, some engineering input, in terms of guidelines, useful to build similar road pavements from bauxite residue in the future, are herewith presented.
\end{abstract}

Keywords: assessment, road construction, bauxite residue.

\section{INTRODUCTION}

The industrial expansion and the development of the construction sector worldwide are constantly dependent on the possibilities of raw materials supply. These materials may be costly or rare but, even more importantly, their extraction and use may be harmful to the environment and to the ecosystem. For this reason, during the last decades, the construction sector has been exploring alternative sources of raw materials, especially, recycled materials and industrial by-products. This is, to put it simply, the concept of the circular economy, which stresses the need to minimise energy and material waste.

In the road engineering sector, research has been directed to waste materials and byproducts, which present adequate workability, high strength and long durability, in order to be introduced as structural constituents in road construction projects [14]. Recyclable materials, such as concrete fragments, bituminous lifts and unbound aggregates, may be recovered from existing road pavements and structures while industrial by-products, such as fly ash, steel slags and foundry sands, can be found in large quantities in most developed countries.

The main challenge for the engineering researchers is to develop testing procedures, application practices and reliable standards facilitating the use of recyclable and recycled materials in the road construction field. The use of these secondary materials of high-added value in the road construction field presents obvious advantages: it safeguards the environment and offers alternative sources of primary materials wherever these are rare or too expensive. Relevant research has confirmed the suitability of several secondary materials 
in engineering applications. Fly ash, for instance, exhibits a binding performance and has been used as a substitute of Portland cement [21]. For other materials, such as, slags, glass, rubber tires, shales, sulphate wastes, etc. there are advantages and drawbacks in view to potential application and, for this reason, systematic research keeps going on.

A rather uncharted field of research of secondary materials is the potential use of bauxite residue (BR), the solid remainder of the bauxite treatment by the Bayer process, in the road construction sector [7], [21]. This construction sector seems quite promising since large quantities of materials are required for construction and may be utilised even in minor road projects. In this regard, a full-scale investigation of bauxite residue properties and a technoeconomic impact assessment, in view to application in the road-engineering sector, would be highly beneficial to construction costs but also to the environment. In fact, despite systematic efforts of alumina production companies worldwide for BR recycling, it seems that, actually, the greatest part of the by-product is disposed to deposit sites following non-environmentfriendly processes [5].

During the last two decades, significant research has been undertaken to suggest potential effective use of the by-product, including extraction of rare metals, production of ceramics, painting agents, fertilizers, geotechnical applications [2], [6], use in cement industry [10], and other industrial applications [11], [16], [18], [20]. However, potential use of this byproduct in road engineering projects, engaging big volumes of earthwork, is far from being fully investigated [8].

The Highway Engineering Laboratory of the Aristotle University of Thessaloniki started exploring the properties of bauxite residue and possible engineering applications in the 1990s. Research was oriented to physical and to strength properties of the by-product and of mixtures with natural soils and aggregates. Research findings over time and, especially, the installation of an industrial filter press, used to separate the solid fraction of BR, helped push forward the implementation of the innovative technique and led to the project hereby presented. The main innovative issue was the use of large quantities of BR in construction of pavement courses of a local road in Boetia, in the vicinity of the industrial site of "Aluminium of Greece". The road structure was designed to bear heavy traffic loads and to maintain its integrity under adverse weather events.

In the present paper, the main aspects and figures of the construction process are outlined. The scope of this full-scale project was to construct a low-cost and high quality BR road, operating under real traffic conditions, and to assess its performance in short and long term.

Similar research on a fraction of the by-product, called "red sand", has been undertaken by the Curtin University in Australia [13], [14]. The mixture applied consisted of red sand and two pozzolanic activators, fly ash and limekiln dust, with excellent results.

\section{BAUXITE RESIDUE PROPERTIES}

In Greece, BR is produced at the industrial site of "Aluminium of Greece". Estimates raise the annual production of bauxite residue to 500,000-750,000 tonnes. A large part of the byproduct is disposed to the sea while some fields of re-utilisation, such as, cement production, extraction of metals and manufacturing of ceramics, absorb a smaller part of the total production.

The chemical composition of the material depends on the bauxite ore characteristics. Iron and other metal oxides constitute the chemical structure of bauxite residue. Chemical analysis through laboratory testing by AUTH, over 20 years of experimental studies [6], [12], revealed a heterogeneity of the by-product (Table 1) and a wide range of variation of the main constituents. It seems, however, that this range is much wider on a worldwide scale [1]. 
Table 1: Chemical composition of bauxite residue [1], [6], [12].

\begin{tabular}{|c|c|c|}
\hline $\begin{array}{c}\text { Chemical } \\
\text { composition }\end{array}$ & $\begin{array}{c}\text { Bauxite residue } \\
(\%)(\text { Greece })\end{array}$ & $\begin{array}{c}\text { Typical values } \\
\text { worldwide (\%) }\end{array}$ \\
\hline $\mathrm{Fe}_{2} \mathrm{O}_{3}$ & $40-51$ & $30-60$ \\
\hline $\mathrm{Al}_{2} \mathrm{O}_{3}$ & $15-25$ & $10-20$ \\
\hline $\mathrm{CaO}$ & $7-13$ & $2-8$ \\
\hline $\mathrm{SiO}_{2}$ & $7-10$ & $3-50$ \\
\hline $\mathrm{TiO}_{2}$ & $5-7$ & Trace-15 \\
\hline $\mathrm{Na}_{2} \mathrm{O}$ & $1-3$ & $2-10$ \\
\hline
\end{tabular}

Table 2: Sieve size analysis of bauxite residue [7], [12].

\begin{tabular}{|l|c|c|c|c|c|c|c|}
\hline Sieve & No 10 & No 16 & No 40 & No 80 & No 100 & No 200 & $45 \mu \mathrm{m}$ \\
\hline \% passing & $98-100$ & $97-100$ & $95-100$ & $91-94$ & $90-94$ & $84-86$ & 80 \\
\hline
\end{tabular}

Table 3: Physical properties of bauxite residue [7], [12].

\begin{tabular}{|c|c|c|c|c|c|}
\hline \multicolumn{3}{|c|}{ Atterberg limits } & Permeability & Sand equivalent & Specific gravity \\
\hline WL & WP & IP & $\mathrm{k}(\mathrm{cm} / \mathrm{s})$ & SE & $\gamma \mathrm{s}\left(\mathrm{t} / \mathrm{m}^{3}\right)$ \\
\hline $35-39$ & $28-33$ & NP-9 & $10^{-4}$ & - & $3.1-3.4$ \\
\hline
\end{tabular}

Laboratory tests yielded loss on ignition values LOI $=5-12 \%$ while alkalinity was found $\mathrm{pH}=10.8-12.5$.

Bauxite residue is a very fine red-coloured material, having an average particle size $<10 \mu \mathrm{m}$. The gradation curve of the material was determined by laboratory analyses according to European Standards. Laboratory tests on samples of different origin confirmed slight variation in the gradation curve of the material presenting a major fraction smaller than $45 \mu \mathrm{m}$ (Table 2).

Despite its fine gradation, the material exhibits low to negligible plasticity (Table 3 ). This is mainly due to the uniformity of the grains, which does not contribute to plastic performance of the residue [3], [12]. Laboratory testing did not lead to determination of sand equivalent.

Dealing with environmental risks and probable effects to subsurface aquifers, it must be stressed that standard leaching tests (TCLP, Italian leaching test) applied to bauxite residue have reported leached concentrations of trace metals well below the threshold concentrations. The absence of severe eco-toxicological or genotoxic effects of this material has been also reported. All these studies suggest that the use of bauxite residue is safe in terms of metal leachability and toxicity [9], [19].

\section{THE DESIGN CONCEPT}

The scope of the pilot project was to introduce large quantities of the by-product into a pavement structure apt to operate under real traffic loads. The local road was planned to bear significant traffic loads, since trucks of gross vehicle weight of $30 \mathrm{t}$ constituted the main load component on the pavement.

The pavement structure should be designed to:

- $\quad$ exhibit sufficient shear strength to bear heavy traffic loads;

- undergo negligible to zero permanent deformation/ rutting;

- $\quad$ resist precipitation impact / erosion effects. 
Relevant strength tests were carried out in the laboratory to determine strength properties and strength parameters of the by-product, namely Proctor/CBR tests and unconfined compression tests ( 7 days curing), under different soaking conditions (Table 4). All specimens were composed of BR and bauxite aggregates $(d=1-2 \mathrm{~cm})$ to improve the strength properties of the material.

It is obvious that the performance of the material is very different under soaking and dry conditions. Dry specimens exhibited high strength and, therefore, under similar conditions, no serious distress to the road structure should be expected under heavy loads. Protection of the material against immersion and erosion seemed to be absolutely mandatory. It was mainly the necessity to control water effects that dictated the introduction of fly ash into the mixes. Fly ash seemed to act partly as a hydraulic binder but much more, as an additive to control aggressive water effects.

\section{THE ENGINEERING DESIGN OF THE BR PAVEMENT}

To date, there are no national or international specifications for utilisation of BR in construction of road bases and subbases. The specifications applied [17] concern hydraulically bound road bases and subbases and make reference to the valid EN standards [4].

Four different compositions of bauxite residue were investigated with $10 \%$ or $20 \%$ of bauxite aggregates, incorporating fly ash (3-4\%) as an additive. Laboratory tests were conducted to determine compaction characteristics (Table 5) and the bearing capacity of the

Figure 1: Strength characteristics under different soaking conditions.

\begin{tabular}{|l|c|c|c|c|}
\hline & \multicolumn{2}{|c|}{ CBR values } & \multicolumn{2}{c|}{$\begin{array}{c}\text { Unconfined compression } \\
\left(\mathrm{kg} / \mathrm{cm}^{2}\right)\end{array}$} \\
\hline BR/BA = & $90 / 10$ & $80 / 20$ & $90 / 10$ & $80 / 20$ \\
\hline Soaked specimens & 26 & 27 & 2.8 & 2.9 \\
\hline Unsoaked specimens & 85 & 103 & 7.8 & 9.4 \\
\hline
\end{tabular}

Table 4: Results of compaction test (Proctor/CBR).

\begin{tabular}{|c|c|c|c|c|c|c|c|c|c|}
\hline $\begin{array}{l}\text { Number } \\
\text { of blows }\end{array}$ & \multicolumn{3}{|c|}{10} & \multicolumn{3}{|c|}{30} & \multicolumn{3}{|c|}{65} \\
\hline $\begin{array}{l}\text { Displace } \\
\text { ment } \\
(0.01 \mathrm{~mm})\end{array}$ & $\begin{array}{c}\text { Resistance } \\
\text { to } \\
\text { penetration } \\
(\mathrm{mm})\end{array}$ & $\begin{array}{c}\text { Load } \\
\mathrm{kg}\end{array}$ & $\begin{array}{l}\text { Pressure } \\
\mathrm{kg} / \mathrm{cm}^{2}\end{array}$ & $\begin{array}{c}\text { Resistance } \\
\text { to } \\
\text { penetration } \\
(\mathrm{mm})\end{array}$ & $\begin{array}{c}\text { Load } \\
\mathrm{kg}\end{array}$ & $\begin{array}{c}\text { Pressu } \\
\text { re } \\
\mathrm{kg} / \mathrm{cm} \\
2\end{array}$ & $\begin{array}{c}\text { Resistanc } \\
\text { e to } \\
\text { penetratio } \\
\mathrm{n}(\mathrm{mm})\end{array}$ & $\begin{array}{c}\text { Load } \\
\mathrm{kg}\end{array}$ & $\begin{array}{l}\text { Pressure } \\
\mathrm{kg} / \mathrm{cm}^{2}\end{array}$ \\
\hline 0.64 & 26 & 92 & 4.76 & 95 & 337 & 17.41 & 83 & 294 & 15.21 \\
\hline 1.27 & 39 & 138 & 7.15 & 234 & 827 & 42.76 & 215 & 761 & 39.31 \\
\hline 1.91 & 49 & 174 & 8.98 & 302 & 1067 & 55.14 & 368 & 1299 & 67.15 \\
\hline 2.54 & 60 & 213 & 11.00 & 344 & 1215 & 62.78 & 461 & 1626 & 84.02 \\
\hline 5.08 & 91 & 323 & 16.68 & 459 & 1619 & 83.66 & 697 & 2448 & 126.51 \\
\hline 7.62 & 117 & 415 & 21.44 & 549 & 1934 & 99.93 & 860 & 3007 & 155.39 \\
\hline \multicolumn{10}{|c|}{ TIME $\Sigma$ CBR values } \\
\hline CBR1 & \multicolumn{3}{|c|}{$11.00 *(100 / 70.3)=16$} & \multicolumn{3}{|c|}{$62.78 *(100 / 70.3)=89$} & \multicolumn{3}{|c|}{$84.02 *(100 / 70.3)=120$} \\
\hline CBR2 & \multicolumn{3}{|c|}{$16.68 *(100 / 105.5)=16$} & \multicolumn{3}{|c|}{$83.66^{*}(100 / 105.5)=79$} & \multicolumn{3}{|c|}{$126.51 *(100 / 105.5)=120$} \\
\hline
\end{tabular}


Table 5: Strength properties of bauxite residue mixtures.

\begin{tabular}{|c|c|c|c|c|c|}
\hline & \multirow[b]{2}{*}{ Material mixtures } & \multirow{2}{*}{$\begin{array}{c}\mathrm{W}_{\mathrm{OPM}} \\
(\%)\end{array}$} & \multirow{2}{*}{$\begin{array}{c}\gamma_{\mathrm{OPM}} \\
\left(\mathrm{t} / \mathrm{m}^{3}\right)\end{array}$} & \multicolumn{2}{|c|}{ CBR } \\
\hline & & & & 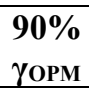 & $\begin{array}{l}95 \% \\
\gamma \mathrm{OPM}\end{array}$ \\
\hline 1 & $\mathrm{BR} / \mathrm{BA}=90 / 10(\%)$ & 25 & 1.76 & 67 & 85 \\
\hline 2 & $\mathrm{BR} / \mathrm{BA}=90 / 10(\%)+\mathrm{FA}(3 \%)$ & 25 & 1.76 & 82 & 110 \\
\hline 3 & $\mathrm{BR} / \mathrm{BA}=80 / 20(\%)$ & 23 & 1.81 & 80 & 103 \\
\hline 4 & $\mathrm{BR} / \mathrm{BA}=80 / 20(\%)+\mathrm{FA}(3 \%)$ & 23 & 1.81 & 82 & 108 \\
\hline
\end{tabular}

BR/BA mixes (Table 6).

The following mix design bauxite residue/bauxite chippings/fly ash was chosen for application after laboratory experiments on compaction strength properties:

- $\quad$ bauxite residue $=90 \%$;

- $\quad$ bauxite aggregates $(\mathrm{d}<1 "=2.5 \mathrm{~cm})=10 \%$;

- $\quad$ fly ash $=3 \%$.

It must be noticed that all mixes exhibit very high strength characteristics $(\mathrm{CBR}=$ 85-110), normally unexpected for a material of fine soil gradation. The effect of fly ash is noticeable but not critical. High strength must be attributed to binding effects of bauxite residue itself. The main advantages of the prevailing mix design are found to be the big volume of bauxite residue utilised, the significant strength and the satisfactory workability and resistance to erosion of a roadway BR structure.

The mix composition chosen for application does not observe the totality of provisions for hydraulically bound bases [17]. The plasticity index of the BR, IP ( $\max )=9<25$ and the resistance to wear, Los Angeles $=32-38<40$, conform to the specifications [17] but the gradation does not fit into the limits set by the EN standards [4]. However, since the main objective was to utilise a secondary material of high strength in large quantities, the aforesaid mix design was assessed suitable for application and subsequent monitoring.

\section{THE CONSTRUCTION STAGE}

Bauxite residue, the main constituent of the mixture, was retrieved from the industrial filter press where adequate processing provided a material of low water content $(\mathrm{W}=15 \%)$ and low heterogeneity. Bauxite aggregates were transported to the work site from provisional deposits in the vicinity of the industrial area. The issue of supply and transportation of fly ash constituted, and will constitute, in every similar case of BR application, a serious problem which should be properly addressed to ensure the success of the construction. Within this context, the proposed percentage of fly-ash was the minimum required for engineering purposes, compatible with the cost-benefit objective of the project.

Before any construction, it was judged necessary to verify that all constitutive materials were clean and free of contaminants, such as soil, wood and clay. The mixing process of the constituents took place on site, using loaders and other equipment, just before the laying of the material. The homogenous distribution of the fly-ash within the mixture is crucial to the success of the project. Moisture content should be very low $(\mathrm{W}<5 \%)$ during the mixing process, otherwise there is a risk of chemical reaction before laying and of potential failure during construction. 


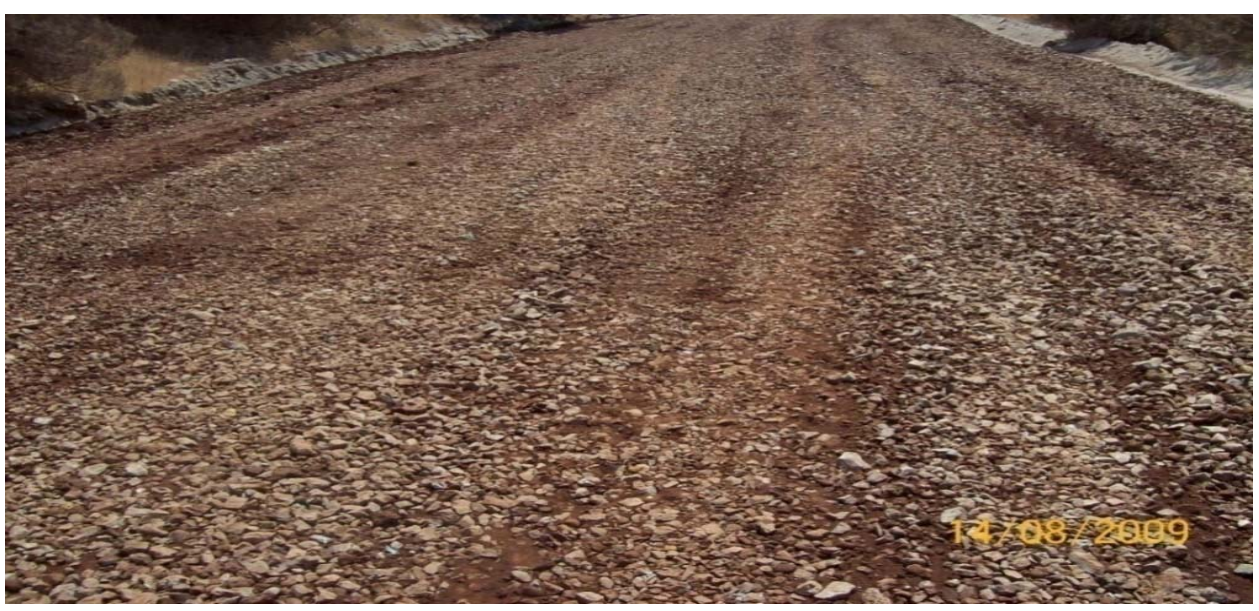

Figure 2: Initial construction of the BR road.

The first stage of construction consisted of grubbing and clearing the existing surface of the local road, followed by water spreading. The main earthwork operations were carried out by a grader and a loader, laying the material on a $6.0 \mathrm{~m}$. wide subgrade surface, at a thickness of $12 \mathrm{~cm}$ and a length of $1200 \mathrm{~m}$. Before compaction, additional bauxite aggregates, at a rate of $20 \mathrm{~kg}$ per square meter, were spread on the gravel surface (Fig. 1) to improve bearing capacity. The compaction was carried out by a light non-vibrating roller of $8 \mathrm{t}$.

The final outcome was very satisfactory, with the exception of some segments where excessive dust on the pavement surface appeared thus creating problems. This functional defect vanished after some time. The overall performance was very good, accounting for standards of gravel roads. Nevertheless, it was mainly the dust problem that dictated, in 2011, the overspreading of an asphalt concrete layer on top of the BR gravel road.

The unpaved local road has been under traffic for 24 months before laying the asphalt concrete course. The asphalt concrete layer of $5 \mathrm{~cm}$ of thickness was laid after spreading an asphaltic tack coat on the gravel pavement. The asphalt concrete consisted of limestone aggregates, following a dense mix design at a binder percentage of 5\%. The average width of the asphalt surface, over the gravel base course, was $5.5 \mathrm{~m}$.

\section{THE ENGINEERING ASSESSMENT}

The engineering assessment took place in 2018, 9 years after the initial construction and 7 years after the surfacing by an asphalt course. Average daily traffic rises up to 200 trucks, half of which are fully loaded at $30 \mathrm{tn}$. Visual survey and site measurements were used to conduct the assessment.

The asphalt surface layer exhibited no signs of major distress; no local subsidence, no potholes, no severe cracking (Fig. 2). Despite the obvious under design of the pavement structure, the roadway did not suffer serious damage.

Local measurements recorded hairline cracks along the wheel track at a rate of $30 \%$ of the whole length of the road and some rutting ranging from $0.5-1 \mathrm{~cm}$ along the wheel track. Due to differentiation in applied loads, distress is reasonably more apparent in the direction from the industrial plant to the deposit area. However, this local deterioration of the pavement structure is very limited (Fig. 3) and creates no problem to traffic operations along the BR road. 


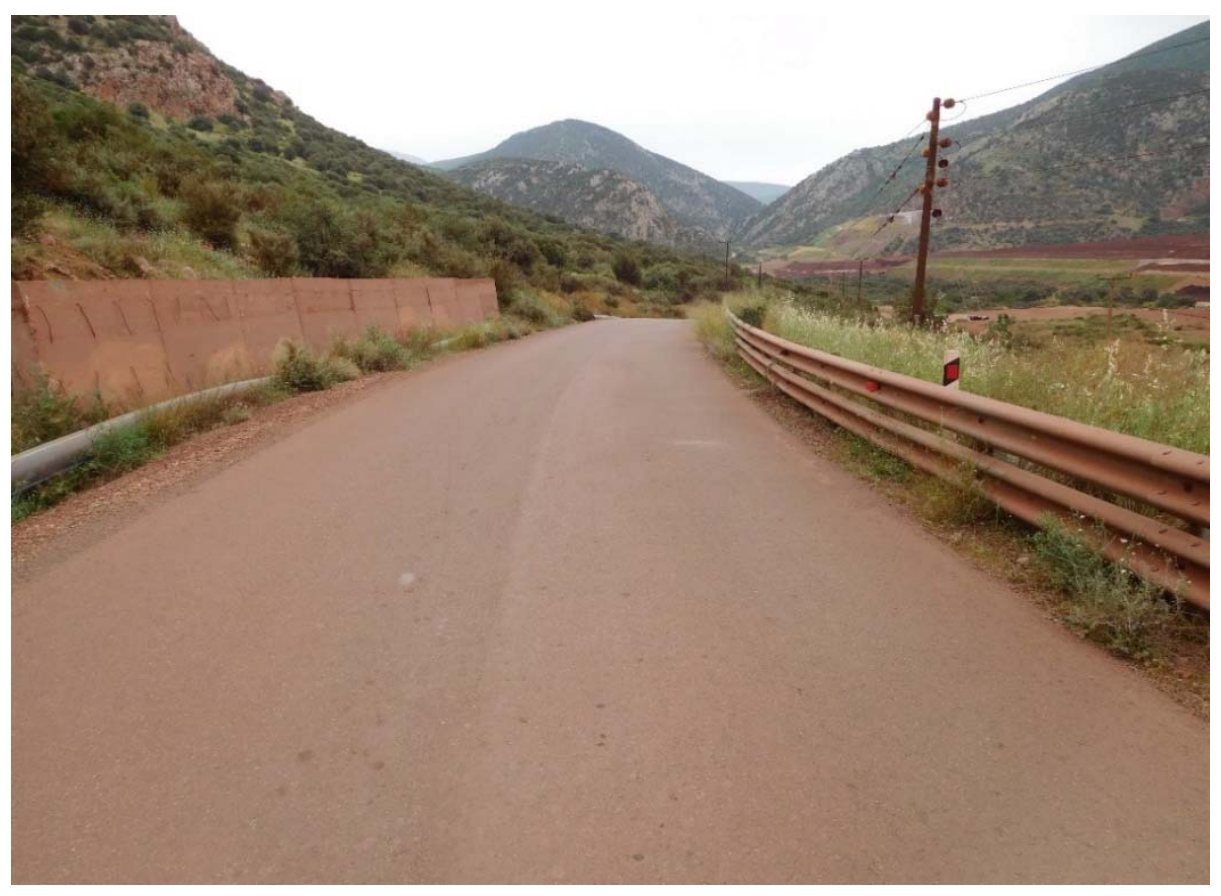

Figure 3: The BR roadway under real traffic conditions in 2018.

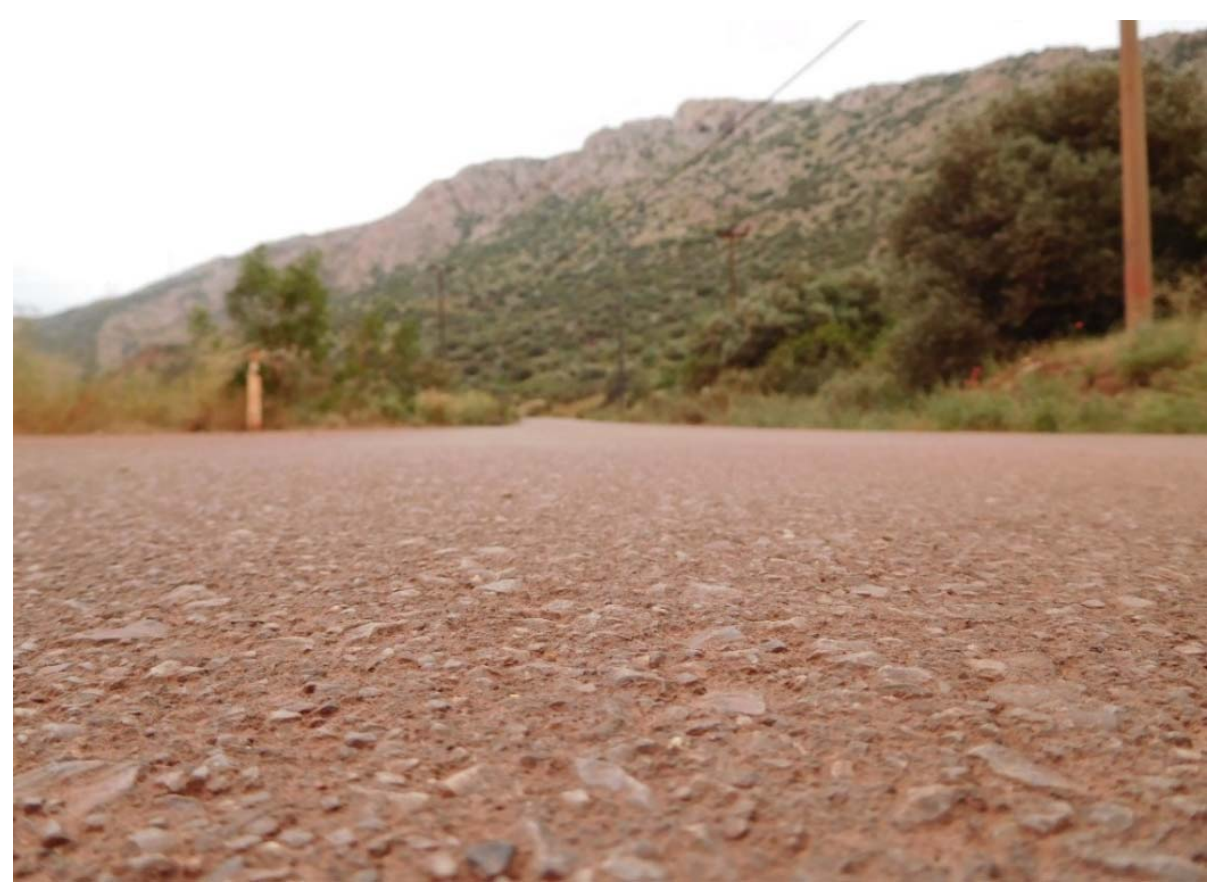

Figure 4: The roadway surface. 


\section{CONCLUSIONS AND PERSPECTIVES}

The engineering assessment of the road structure, after 9 years of operating conditions, unveils beneficial effects of bauxite residue application in road construction. Under heavy traffic conditions, unusual for a local road, the roadway structure appears intact and undamaged, bearing no significant distress. The material retrieved from the industrial filter press bound by fly ash, mainly to control water effects, exhibited a very satisfactory performance. The applied mix design, the additive introduced and the construction process proved effective and may constitute a guide to future construction projects.

The main impediment to a wide application of the technique remains the transport cost, which may be significant. In countries where gravel and natural aggregates can be easily found, this constitutes a serious drawback. Thus, in the case of "Aluminium of Greece", for the time being, the technique cannot extend to projects far from the production plant and can only apply to local and regional roads as a reliable alternative to traditional pavements.

\section{REFERENCES}

[1] Capron, T.L., An evaluation of alternative bauxites for Kaiser's Bayer plant in Gramercy Louisiana. Light Metals, pp. 11-14, 1998.

[2] Das, K.S., Rout, S. \& Alam, S., Characterisation of red mud as a subgrade construction material. Researchgate, 2015.

[3] Deelwal, K., Dharavath, K. \& Kulshreshtha, M., Evaluation of characteristic properties of red mud for possible use as a geotechnical material in civil construction. International Journal of Advances in Engineering \& Technology, 7(3), pp. 1053-1059, 2014.

[4] EN13242-2002, Aggregates for unbound and hydraulically bound materials for use in civil engineering work and road construction.

[5] FHWA, Recycled materials in European Highway Environments. Uses, Technologies and Policies, International Technology Exchange Program, Report PL-00-025, 2000.

[6] Kehagia, F., A successful pilot project demonstrating the re-use potential of bauxite residue in embankment construction. International Journal "Recourses, Conservation and Recycling”, 54, pp. 417-421, 2010.

[7] Kehagia, F., Construction of an unpaved road using industrial by-products. Transactions WSEAS on Environment and Development, pp. 160-168, 2014.

[8] Laboratoire Regional d'Aix-en-Provence, Utilisation des residus de bauxite en technique routiere, Rapport Technique, 1977.

[9] Layman's Report, Rehabilitation of abandoned bauxite surface mines using alumina red mud as filler (REFILL), LIFE03 ENV/GR/000213, 2006.

[10] Lima, M., Thives, L., Haritonovs, V. \& Bajars, K., Red mud application in construction industry: Review of benefits and possibilities. IOP Conference Series: Materials Science and Engineering, 251, 2017.

[11] Martinent-Catalot, V., Lamerant, J.-M., Tilmant, G., Bacou, M.-S. \& Ambrosi, J.P., Bauxaline: A new product for various applications of Bayer Process red mud. Light Metals, pp. 125-131, 2002.

[12] Mouratidis, A. \& Nikolidakis, P., On the use of red mud in highway engineering. Proceedings of the 2nd Hellenic Congress on Asphalt Mixes and Pavements, Thessaloniki, Greece, pp. 441-452, 1996.

[13] Nikraz, H.R., Jitsangiam, P. \& Jamieson, E., Sustainable use of a bauxite residue in terms of roadway materials. Researchgate, 2007.

[14] Nikraz H.R. \& Jitsangiam P., Coarse bauxite residue for roadway construction materials. Journal of Pavement Engineering, 14(3), pp. 265-273, 2013. 
[15] OCDE, Recherche Routiere, Utilisation des dechets et sous-produits en technique routiere, Rapport Technique par Groupe d'Experts, p. 174, 1977.

[16] Paramguru, R., Rath, P. \& Misra, V., Trends in red mud utilization-a review. Mineral Processing \& Extractive Metallurgy Review, 26, pp. 1-29, 2005.

[17] PETEP 05-03-05-01, Hydraulically bound road bases and subbases. National Specifications, p. 21, 2006. (In Greek.)

[18] Pilurzu, S., Cucca, L., Tore, G. \& Ullu, F., New research proposals for utilization and disposal of bauxite red mud from Bayer process. Proceedings of the Global Symposium on Recycling, Waste Treatment and Clean Technology, pp. 471-480, 1999.

[19] Rubinos, D., Spagnoli, G. \& Barral, M.T., Assessment of bauxite refining residue (red mud) as a liner for waste disposal facilities. International Journal of Mining, Reclamation and Environment, 29(6), pp. 433-452, 2013.

DOI: 10.1080/17480930.2013.830906.

[20] Schwarz, M. \& Lalik, V., Possibilities of exploitation of bauxite residue from alumina production. Recent Researches in Metallurgical Engineering-from Extraction to Forming, ed. H. Ahuett-Garza, InTech, 2012.

[21] Tsohos, G. \& Mouratidis, A., Effective utilization of fly ash in road construction. Proceedings of the 4th BITMAT, Nottingham, pp. 181-185, 2002.

[22] Vijaya, H., Wesly, S. \& Kulkarni, P., Assessment of red mud as a construction material: a review. Indian Journal of Scientific Research, 17(2), pp. 473-478, 2018. 